\title{
A study on knowledge, attitude and practice regarding blood donation in an urban community, Chennai
}

\author{
Anand $\mathrm{N}^{1}{ }^{*}$, Inban $\mathrm{P}^{2}$ \\ DOI: https://doi.org/10.17511/ijphr.2018.i1.05 \\ 1* Anand N, Assistant Professor, Department of Community Medicine, Government Medical College, Omandurar, Chennai, India. \\ 2 Pugazhendi Inban, Third year MBBS Student, Government Medical College, Chennai, Tamilnadu, India.
}

Background: Blood transfusion plays a vital role in saving the life of those patients requiring transfusion. Assessment of awareness, attitude and practice regarding blood donation will help in creating effective health education strategy to enhance blood donation. Objectives: To assess the knowledge, attitude, and practices regarding blood donation among individuals aged 18-60 years in an urban community of Chennai and to identify the factors associated with blood donation. Methods: A cross-sectional study was carried out in pudupet on the months of May and June, 2017. Table of random numbers was used to recruit a total of 300 study participants. A pilot tested semi structured, questionnaire was employed as a data collection tool. Multiple logistic regression analysis was used to examine association between the independent variables and the dependent variables. Results: Among our study subjects, $45 \%$ of them had good knowledge on blood donation and $44 \%$ of our subjects had a correct attitude towards blood donation. Only $33.3 \%$ of them had good practices towards blood donation. The most common reason quoted for not donating blood was that they were more bothered about their own health which by donating blood would lead on to some health problems. Conclusion: The present study shows an average prevalence of knowledge and attitude among the study subjects whereas when it comes to practice it was found to be less. There should be a regularly scheduled awareness creation and voluntary blood donation campaigns organized at the community level.

Keywords: Attitude, Blood donation, Knowledge

Corresponding Author

Anand N, Assistant Professor, Department of Community Medicine, Government Medical College, Omandurar, Chennai, India.

Email: drnanand27@gmail.com
How to Cite this Article

To Browse

Anand N, Inban P. A study on knowledge, attitude and practice regarding blood donation in an urban community, Chennai. Public Health Rev Int J Public Health Res. 2018;5(1):35-44.

Available From

https://publichealth.medresearch.in/index.php/ijphr/ article/view/78

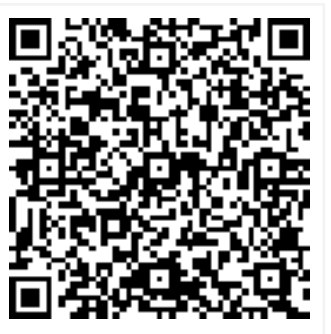




\section{Introduction}

Blood is a specialized body fluid in humans and other animals which performs many important functions within the body. Blood has always been one of the basic requirements of human life. Blood transfusion plays a vital role in saving the life of those patients requiring transfusion. Ignorance, fear and misconception about blood donations and lack of voluntary blood donation organizations are major constraints in developing countries to facilitate voluntary blood donation.

Considering the estimated shortfall of 3 to 4 million units of blood annually in India, more awareness must be created among all strata of population especially among youngsters on importance of blood donation [1]. Most of the components of blood used for transfusions have a short shelf life and maintaining a constant supply is a persistent problem and the need for blood transfusion may occur at any time and the unavailability of blood has led to deaths and many patients suffering from illhealth.

In many countries, there is an inadequate supply of safe blood, and blood services face the challenge of making sufficient blood available, while also ensuring its quality and safety. There is a marked difference in the level of access to safe blood between high- and low-income countries [2].

An adequate supply of safe blood can only be ensured through regular donations by voluntary unpaid blood donors [3]. Understanding blood donors motivations are crucial to improve the effectiveness of donor recruitment and retention programmes [4].

There are very few studies done in the community, where the awareness about blood donation needed to be strengthened and assessment of awareness, attitude and practice regarding blood donation will help in creating effective health education strategy to enhance blood donation. Thus, this study was primarily designed to assess the knowledge, attitudes and practice regarding blood donation in an urban community

\section{Objectives}

01. To assess the knowledge, attitude, and practices regarding blood donation among individuals aged $18-60$ years in an urban community of Chennai.
02. To identify the factors associated with blood donation.

\section{Methodology}

- Study design: Cross sectional study

- Study area: Pudupet, urban field practice area of government medical college, Omandurar government estate, Chennai in south India.

- Study population: Individuals aged 18-60 years.

- Study period: Two months (May and June 2017).

- Sample size: Sample size for this study was calculated to be 278 , based on $77.6 \%$ prevalenceof knowledge and 5\% absolute precision with $95 \%$ confidence level and this was rounded off to 300 [5].

- Sampling technique: Simple random sampling (The table of random numbers).

- Inclusion criteria: Those aged 18-60 years (the eligible age group for blood donation as per the Indian blood bank guidelines) and willing to participate were included in the study [6].

- Exclusion criteria: Critically ill adults were excluded from the study.

- Study tool: A semi structured questionnaire was prepared by referring various published articles and wasvalidated by experts. The questionnaire was further refined by doing a pilot study.

- Brief procedure: The study was carried out in pudupet, urban field practice area of government medical college, Omandurar government estate, Chennai. The ethical clearance was sought from the Institutional Ethical Committee.

The urban field practice area, pudupet has a total population of about approximately 56328 comprising of five sectors with population of 11081 , $11631,10808,11425$ and 11383 in sector a, sector b, sector $\mathrm{c}$, sector $\mathrm{d}$ and sector e respectively.

From the family register of each sector, 60 families were chosen randomly by using the table of random numbers to arrive at a total sample size of 300 .

If the designated house was locked during the visit, household members in the next house was considered as study subjects. 
In case of multiple eligible adults in the same selected house hold, only one of them was chosen randomly using the lottery method for interview.

Informed written consent from each participant (18 to 60 years) was maintained.

Semi structured questionnaire was administered, by using the interview method by the house-to-house visits.

The questionnaire collects data related to demographic variables, knowledge, attitude and practice regarding blood donation.

Statistical analysis: The data collected were coded and entered in Microsoft office excel worksheet and then transferred to SPSS.v.22 for analysis.

Mean and standard deviation were calculated for all the parametric variables. Multiple logistic regression analysis was used to examine the association between the independent variables and the dependent variable at $95 \%$ confidence level with $\mathrm{p}<0.05$ considered as statistically significant.

\section{Results}

Table 1 shows the socio-demographic profile of the study population. It is seen from the table that majority of the study subjects were in the age group between 41 - 50 years, with a mean age of $39.7+$ 9.17 years and the male: female ratio was $0.76: 1$, where the females outnumbered the males. Majority of the study subjects had completed their education upto middle school (54.3\%) and most of the females were housewives (un-skilled) and most of the professionals and semi-skilled were males. Among our study subjects majority of them were Hindus (78.6\%) and most of them belong to class II socio-economic status $(46.6 \%)$ and none of them belong to class $\mathrm{V}$ socio-economic statusbased on modified B G Prasad classification.

Table-1: Socio-demographic profile of the study subjects.

\begin{tabular}{|c|c|c|c|}
\hline \multicolumn{2}{|c|}{ Socio-demographic variable } & Frequency $(n=300)$ & Percentage \\
\hline \multirow[t]{5}{*}{ Age group } & $10-20$ & 4 & $1.3 \%$ \\
\hline & $21-30$ & 53 & $17.6 \%$ \\
\hline & $31-40$ & 86 & $28.6 \%$ \\
\hline & $41-50$ & 124 & $41.3 \%$ \\
\hline & $51-60$ & 33 & $11 \%$ \\
\hline \multirow[t]{2}{*}{ Gender } & Male & 130 & $43.3 \%$ \\
\hline & Female & 170 & $56.6 \%$ \\
\hline
\end{tabular}

\begin{tabular}{|c|c|c|c|}
\hline \multirow[t]{5}{*}{ Education } & Primary schoo & 3 & $1 \%$ \\
\hline & Middle school & 52 & $17.3 \%$ \\
\hline & High school & 163 & $54.3 \%$ \\
\hline & Diploma & 19 & $6.3 \%$ \\
\hline & $\begin{array}{l}\text { Graduate and } \\
\text { above }\end{array}$ & 63 & $21 \%$ \\
\hline \multirow[t]{6}{*}{ Occupation } & Professional & 28 & $9.3 \%$ \\
\hline & $\mid \begin{array}{l}\text { Semi- } \\
\text { professional }\end{array}$ & 3 & $1 \%$ \\
\hline & Skilled & 12 & $4 \%$ \\
\hline & Semi-skilled & 107 & $35.6 \%$ \\
\hline & Unskilled & 146 & $48.6 \%$ \\
\hline & Unemployed & 3 & $1 \%$ \\
\hline \multirow[t]{3}{*}{ Religion } & Hindu & 236 & $78.6 \%$ \\
\hline & Muslim & 31 & $10.3 \%$ \\
\hline & Christian & 33 & $11 \%$ \\
\hline \multirow{4}{*}{$\begin{array}{l}\text { SES (based on Modified BG Prasad } \\
\text { classification) }\end{array}$} & Class I & 66 & $22 \%$ \\
\hline & Class II & 140 & $46.6 \%$ \\
\hline & Class III & 67 & $22.3 \%$ \\
\hline & Class IV & 27 & $9 \%$ \\
\hline
\end{tabular}

Table-2: Knowledge regarding blood donation among our study subjects.

\begin{tabular}{|c|c|c|c|}
\hline \multicolumn{2}{|c|}{ Knowledge related questions } & $\begin{array}{l}\text { Correct } \\
\text { response } \\
\text { (frequency) }\end{array}$ & $(\%)$ \\
\hline \multicolumn{2}{|c|}{ Aware of your blood group? } & 205 & $68.3 \%$ \\
\hline \multicolumn{2}{|c|}{$\begin{array}{l}\text { Are you aware that donating blood is good } \\
\text { for donors health? }\end{array}$} & 104 & $34.6 \%$ \\
\hline \multicolumn{2}{|c|}{$\begin{array}{l}\text { Is there any age limitation for blood } \\
\text { donation? }\end{array}$} & 79 & $26.3 \%$ \\
\hline \multicolumn{2}{|c|}{$\begin{array}{l}\text { Can blood donation transmit the infection to } \\
\text { donor? }\end{array}$} & 218 & $72.6 \%$ \\
\hline \multicolumn{2}{|c|}{$\begin{array}{l}\text { Can blood donation transmit the infection to } \\
\text { recipient? }\end{array}$} & 216 & $72 \%$ \\
\hline \multicolumn{2}{|c|}{$\begin{array}{l}\text { Are you aware that potential donors are } \\
\text { screened for transfusion-transmissible } \\
\text { infections? }\end{array}$} & 119 & $39.6 \%$ \\
\hline \multirow[t]{5}{*}{$\begin{array}{l}\text { Can any of the } \\
\text { following people } \\
\text { donate? }\end{array}$} & Pregnant women & 32 & $10.6 \%$ \\
\hline & Menstruating women & 173 & $57.6 \%$ \\
\hline & Lactating women & 42 & $14 \%$ \\
\hline & Diabetes patients & 236 & $78.6 \%$ \\
\hline & $\begin{array}{l}\text { A Person who had } \\
\text { consumed alcohol }\end{array}$ & 270 & $90 \%$ \\
\hline \multicolumn{2}{|c|}{$\begin{array}{l}\text { Do you know which blood group is called as } \\
\text { universal donor? }\end{array}$} & 87 & $29 \%$ \\
\hline \multicolumn{2}{|c|}{ How often can you donate blood? } & 99 & $33 \%$ \\
\hline \multicolumn{2}{|c|}{$\begin{array}{l}\text { What is the quantity of blood we can donate } \\
\text { each time? }\end{array}$} & 203 & $67.6 \%$ \\
\hline
\end{tabular}


Majority of the study subjects were aware of their blood group (68.3\%). Out of 14 questions in assessing the knowledge on blood donation people who had scored 10 and above are considered as having good knowledge on blood donation and less than 10 are considered as low knowledge on blood donation. Among our study subjects, only $45 \%$ of them had good knowledge on blood donation and the remaining $55 \%$ had a poor knowledge (table 2 ).

Table-3: Attitude towards blood donation among the study subjects.

\begin{tabular}{|l|l|l|}
\hline \multicolumn{1}{|c|}{ Attitude related questions } & $\begin{array}{c}\text { Correct attitude } \\
\text { (frequency) }\end{array}$ & $\begin{array}{l}\text { Perce } \\
\text { ntage }\end{array}$ \\
\hline $\begin{array}{l}\text { Do you think blood donation is harmful to } \\
\text { donors? }\end{array}$ & 71 & $23.6 \%$ \\
\hline $\begin{array}{l}\text { Do you think your act of voluntary blood } \\
\text { donation can motivate others to donate blood? }\end{array}$ & 232 & $77.3 \%$ \\
\hline Do you think donors should be remunerated? & 28 & $9.3 \%$ \\
\hline $\begin{array}{l}\text { Do you think blood donation is life- saving? } \\
\text { Will you donate blood only if your family } \\
\text { member/friend is the recipient? }\end{array}$ & 281 & $93.6 \%$ \\
\hline $\begin{array}{l}\text { Does your family encourage you to donate } \\
\text { blood? }\end{array}$ & 136 & $15.3 \%$ \\
\hline
\end{tabular}

The attitude towards blood donation was assessed by asking 6 questions and people who had mentioned 4 correct responses was considered as good attitude $(n=132)$ and less than 4 are considered as poor attitude (168). Nearly $76 \%$ of the study subjects think that blood donation is harmful to donors and only $44 \%$ of our subjects had a positive and correct attitude towards blood donation (table 3).
Table-4: Practices towards blood donation among the study subjects.

\begin{tabular}{|l|l|l|}
\hline \multicolumn{1}{|c|}{ Practices related questions } & Good practice & Percentage \\
\hline Have you ever donated blood? & 113 & $37.6 \%$ \\
\hline Are you a voluntary donor? & 34 & $11.3 \%$ \\
\hline Have you encouraged others to donate blood? & 153 & $51 \%$ \\
\hline
\end{tabular}

Related to practices on blood donation we asked 3 questions and people who had correctly responded for 2 or more we considered as good practice $(n=100)$ and less than that are considered as bad practice $(n=200)$. So when it comes to practices only $33.3 \%$ of them had good practices towards blood donation and only $37.6 \%$ of our subjects had ever donated blood in their life time (table 4).

\section{Table-5: Reasons quoted by study subjects for not donating blood}

\begin{tabular}{|l|l|l|}
\hline \multicolumn{1}{|c|}{ Reasons for not donating blood } & $\begin{array}{r}\text { Frequency } \\
(\mathrm{n}=\mathbf{1 8 7})\end{array}$ & $\begin{array}{c}\text { Percent } \\
\text { age }\end{array}$ \\
\hline Fear of health problem & 72 & $38.5 \%$ \\
\hline Fear of needle & 9 & $4.8 \%$ \\
\hline Religious prohibition & 1 & $0.5 \%$ \\
\hline Do not know the place to donate & 4 & $2.1 \%$ \\
\hline A friend/family told me not to donate & 16 & $8.5 \%$ \\
\hline I do not like the idea of blood donation & 6 & $3.2 \%$ \\
\hline Lack of opportunity & 36 & $19.2 \%$ \\
\hline The blood banks misuse/sell the blood products & 10 & $5.3 \%$ \\
for monetary benefits & & $1.6 \%$ \\
\hline No remuneration & 3 & \\
\hline
\end{tabular}

The most common reason quoted for not donating blood was that they were more bothered about their own health which by donating blood would lead on to some health problems and few people mentioned that they did not have an opportunity to donate blood (table 5).

Table-6: Logistic regression analysis of the socio-demographic variables and their knowledge on blood donation

\begin{tabular}{|c|c|c|c|c|c|}
\hline \multicolumn{2}{|c|}{ Socio-demographic variable } & \multirow{2}{*}{$\begin{array}{l}\text { Good knowledge }(n=135) \\
0\end{array}$} & \multirow{2}{*}{$\frac{\text { Low knowledge }(n=165)}{4(2.4 \%)}$} & \multirow{2}{*}{$\frac{\text { AOR }}{R}$} & \multirow[t]{2}{*}{$95 \% \mathrm{CI}$} \\
\hline Age group & $10-20$ & & & & \\
\hline & $21-30$ & $28(20.7 \%)$ & $25(15.1 \%)$ & 0.781 & $0.516-0.918$ \\
\hline & $31-40$ & $54(40 \%)$ & $32(19.3 \%)$ & $2.145^{*}$ & $1.915-2.345$ \\
\hline & $41-50$ & $37(27.4 \%)$ & $87(52.7 \%)$ & $1.161^{*}$ & $0.917-1.456$ \\
\hline & $51-60$ & $16(11.8 \%)$ & $17(10.3 \%)$ & 0.317 & $0.167-0.618$ \\
\hline \multirow{2}{*}{ Gender } & Male & $82(60.7 \%)$ & $48(29 \%)$ & $2.715 *$ & $1.919-2.918$ \\
\hline & Female & $53(39.2 \%)$ & $117(70.9 \%)$ & R & \\
\hline \multirow[t]{5}{*}{ Education } & Primary school & 0 & $3(1.8 \%)$ & R & \\
\hline & Middle school & $9(6.6 \%)$ & $43(26 \%)$ & 0.387 & $0.219-0.498$ \\
\hline & High school & $44(32.5 \%)$ & $119(72.1 \%)$ & $2.518^{*}$ & $2.132-2.781$ \\
\hline & Diploma & $19(14 \%)$ & 0 & $2.148 *$ & $1.871-2.458$ \\
\hline & Graduate and above & $63(46.6 \%)$ & 0 & $3.167 *$ & $2.896-3.456$ \\
\hline
\end{tabular}


Anand N. et al: A study on knowledge, attitude and practice

\begin{tabular}{|c|c|c|c|c|c|}
\hline \multirow[t]{6}{*}{ Occupation } & Professional & $28(20.7 \%)$ & 0 & $3.154 *$ & $2.891-3.345$ \\
\hline & Semi-professional & $3(2.2 \%)$ & 0 & $2.891 *$ & $2.641-3.143$ \\
\hline & Skilled & $10(7.4 \%)$ & $2(1.2 \%)$ & $1.145^{*}$ & $0.817-1.415$ \\
\hline & Semi-skilled & $84(62.2 \%)$ & $23(13.9 \%)$ & 0.918 & $0.716-1.236$ \\
\hline & Unskilled & $10(7.4 \%)$ & $136(82.4 \%)$ & 0.714 & $0.561-0.918$ \\
\hline & Unemployed & 0 & $3(1.8 \%)$ & $\mathrm{R}$ & \\
\hline \multirow[t]{3}{*}{ Religion } & Hindu & $104(77 \%)$ & $132(80 \%)$ & $2.176 *$ & $1.987-2.437$ \\
\hline & Muslim & $6(4.4 \%)$ & 25 (15.1\%) & $R$ & \\
\hline & Christian & $25(18.5 \%)$ & $8(4.8 \%)$ & 3.179* & $2.764-3.456$ \\
\hline \multirow[t]{3}{*}{ SES ( based onmodified BG Prasad classification) } & Class I & $60(44.4 \%)$ & $6(3.6 \%)$ & $3.617 *$ & $3.145-3.971$ \\
\hline & Class II & $58(42.9 \%)$ & $82(49.6 \%)$ & 2.984* & $2.541-3.215$ \\
\hline & Class III & $16(11.8 \%)$ & $51(30.9 \%)$ & 1.187 & $0.871-1.431$ \\
\hline
\end{tabular}

*- $\mathrm{P}<0.05$ statistically significant, $\mathrm{R}$ - reference group, AOR - adjusted odds ratio, 95\% CI Confidence interval

Table 6 shows the logistic regression analysis between the socio-demographic factors and the knowledge components and it is inferred from the table that people in the age group between $30-50$ years, male gender, graduates, professionals, semiprofessionals, skilled workers had a better knowledge than people below 30 and above 60 years, females, people educated only upto middle
School and people who were semi-skilled and unskilled and the difference was found to be statistically significant $(p<0.05)$.

Hindus and Christians had a better knowledge than the Muslims and people belonging to class I and class II socio-economic status had a better knowledge than the people belonging to class III and class IV and this difference was found to be statistically significant $(P<0.05)$ and a similar type of results was also seen for attitude and practices towards blood donation among our study subjects (table 7 and 8).

Table-7: Logistic regression analysis of the socio-demographic variables and their attitude towards blood donation.

\begin{tabular}{|c|c|c|c|c|c|}
\hline \multicolumn{2}{|c|}{ Socio-demographic variable } & \multirow[t]{2}{*}{ Good attitude $(n=132)$} & \multirow{2}{*}{\begin{tabular}{|l} 
Poor attitude $(n=168)$ \\
$4(2.3 \%)$
\end{tabular}} & \multirow{2}{*}{$\begin{array}{ll}\text { AOR } \\
R\end{array}$} & \multirow[t]{2}{*}{$95 \% \mathrm{Cl}$} \\
\hline Age group & $10-20$ & & & & \\
\hline & $21-30$ & $28(21.2 \%)$ & $25(14.8 \%)$ & 0.781 & $0.516-0.918$ \\
\hline & $31-40$ & 53 (40.1\%) & $31(18.4 \%)$ & $2.045^{*}$ & $1.815-2.215$ \\
\hline & $41-50$ & $35(26.5 \%)$ & $89(52.9 \%)$ & $1.161^{*}$ & $0.817-1.326$ \\
\hline & $51-60$ & $16(12.1 \%)$ & $17(10.1 \%)$ & 0.317 & $0.167-0.618$ \\
\hline \multirow[t]{2}{*}{ Gender } & Male & $82(62.1 \%)$ & 48 (28.5\%) & $2.835 *$ & $1.989-3018$ \\
\hline & Female & $50(37.8 \%)$ & $120(71.4 \%)$ & $R$ & \\
\hline \multirow[t]{5}{*}{ Education } & Primary school & 0 & $3(1.7 \%)$ & $R$ & \\
\hline & Middle school & $7(5.3 \%)$ & $45(26.7 \%)$ & 0.347 & $0.219-0.498$ \\
\hline & High school & $43(32.5 \%)$ & $120(71.4 \%)$ & $2.508^{*}$ & $2.132-2.781$ \\
\hline & Diploma & $19(14.3 \%)$ & 0 & $2.178^{*}$ & $1.871-2.458$ \\
\hline & Graduate and above & $63(47.7 \%)$ & 0 & $3.217 *$ & $2.896-3.456$ \\
\hline \multirow[t]{6}{*}{ Occupation } & Professional & $28(21.2 \%)$ & 0 & $3.154 *$ & $2.891-3.345$ \\
\hline & Semi-professional & $3(2.2 \%)$ & 0 & $2.891^{*}$ & $2.641-3.143$ \\
\hline & Skilled & $10(7.5 \%)$ & $2(1.1 \%)$ & $1.145^{*}$ & $0.817-1.415$ \\
\hline & Semi-skilled & $83(62.8 \%)$ & $24(14.2 \%)$ & 0.905 & $0.701-1.116$ \\
\hline & Unskilled & $8(6 \%)$ & $138(82.1 \%)$ & 0.634 & $0.531-0.958$ \\
\hline & Unemployed & 0 & $3(1.7 \%)$ & $R$ & \\
\hline
\end{tabular}


Anand N. et al: A study on knowledge, attitude and practice

\begin{tabular}{|l|l|l|l|l|l|}
\hline Religion & Hindu & $104(78.7 \%)$ & $132(78.5 \%)$ & $2.176 *$ & $1.867-2.317$ \\
\cline { 2 - 7 } & Muslim & $4(3 \%)$ & $27(16 \%)$ & $R$ & \\
\cline { 2 - 7 } & Christian & $24(18.1 \%)$ & $9(5.3 \%)$ & $3.179 *$ & $2.734-3.416$ \\
\hline \multirow{3}{*}{ SES (based on BG Prasad classification) } & Class I & $60(45.4 \%)$ & $6(3.5 \%)$ & $3.617 *$ & $3.025-3.911$ \\
\cline { 2 - 7 } & Class II & $58(43.9 \%)$ & $82(48.8 \%)$ & $2.984 *$ & $2.41-3.015$ \\
\cline { 2 - 7 } & Class III & $14(10.6 \%)$ & $53(31.5 \%)$ & 1.187 & $0.871-1.431$ \\
\cline { 2 - 6 } & Class IV & 0 & $27(16 \%)$ & $R$ & \\
\hline
\end{tabular}

*- $\mathrm{P}<0.05$ statistically significant, $\mathrm{R}$ - reference group, AOR- adjusted odds ratio, $95 \% \mathrm{CI}$ - Confidence interval.

Table-8: Logistic regression analysis of the socio-demographic variables and their practices towards blood donation.

\begin{tabular}{|c|c|c|c|c|c|}
\hline \multicolumn{2}{|c|}{ Socio-demographic variable } & Good practices $(n=100)$ & Bad practices $(n=200)$ & AOR & $95 \%$ CI \\
\hline \multirow[t]{5}{*}{ Age group } & $10-20$ & 0 & $4(2 \%)$ & R & \\
\hline & $21-30$ & $20(20 \%)$ & $33(16.5 \%)$ & 0.781 & $0.516-0.918$ \\
\hline & $31-40$ & $48(48 \%)$ & $38(19 \%)$ & $1.375 *$ & $1.115-1.515$ \\
\hline & $41-50$ & $22(22 \%)$ & $102(51 \%)$ & $0.861 *$ & $0.617-1.126$ \\
\hline & $51-60$ & $10(10 \%)$ & $23(11.5 \%)$ & 0.217 & $0.167-0.318$ \\
\hline \multirow[t]{2}{*}{ Gender } & Male & $75(75 \%)$ & $55(72.5 \%)$ & $3.245^{*}$ & $2.989-3.983$ \\
\hline & Female & $25(25 \%)$ & $145(71.4 \%)$ & $R$ & \\
\hline \multirow[t]{5}{*}{ Education } & Primary school & 0 & $3(1.5 \%)$ & $R$ & \\
\hline & Middle school & $2(2 \%)$ & $50(25 \%)$ & 0.217 & $0.189-0.398$ \\
\hline & High school & $30(30 \%)$ & $133(66.5 \%)$ & $2.15^{*}$ & $2.02-2.281$ \\
\hline & Diploma & $14(14 \%)$ & $5(2.5 \%)$ & $2.01 *$ & $1.871-2.358$ \\
\hline & Graduate and above & $54(54 \%)$ & $9(4.5 \%)$ & $2.917 *$ & $2.496-3.356$ \\
\hline \multirow[t]{6}{*}{ Occupation } & Professional & $25(25 \%)$ & $3(1.5 \%)$ & $3.154 *$ & $2.891-3.345$ \\
\hline & Semi-professional & $2(2 \%)$ & $1(0.5 \%)$ & $2.791 *$ & $2.541-3.043$ \\
\hline & Skilled & $7(7 \%)$ & $5(2.5 \%)$ & $1.145^{*}$ & $0.637-1.235$ \\
\hline & Semi-skilled & $60(60 \%)$ & $47(23.5 \%)$ & 0.725 & $0.501-0.916$ \\
\hline & Unskilled & $6(6 \%)$ & $140(70 \%)$ & 0.584 & $0.381-0.758$ \\
\hline & Unemployed & 0 & $3(1.5 \%)$ & $R$ & \\
\hline \multirow[t]{3}{*}{ Religion } & Hindu & $82(82 \%)$ & $154(77 \%)$ & $1.986 *$ & $1.667-2.117$ \\
\hline & Muslim & $1(1 \%)$ & $30(15 \%)$ & R & \\
\hline & Christian & $17(17 \%)$ & $16(8 \%)$ & $2.379 *$ & $2.134-2.616$ \\
\hline \multirow[t]{4}{*}{ SES ( based on modified BG Prasad classification) } & Class I & $50(50 \%)$ & $16(8 \%)$ & $2.917 *$ & $2.625-3.211$ \\
\hline & Class II & $40(40 \%)$ & $100(50 \%)$ & $2.584 *$ & $2.231-2.815$ \\
\hline & Class III & $10(10 \%)$ & $57(28.5 \%)$ & 0.887 & $0.571-1.231$ \\
\hline & Class IV & 0 & $27(13.5 \%)$ & $R$ & \\
\hline
\end{tabular}

*- $\mathrm{P}<0.05$ statistically significant, $\mathrm{R}$ - reference group, AOR- adjusted odds ratio, 95\% CI Confidence interval

\section{Discussions}

The overall level of knowledge in the present study towards blood donation was found to be $45 \%$ which is almost in par with the community based study conducted in the city of Mekelle and a study conducted by Yene work Acham Jemberu $[7,8]$.
However, it is lower than the study conducted among health science students in Addis Ababa (83\%) [9]. The difference in socio-economic status and in educational status with the health science students might explain the discrepancy with the above findings.

Only $33 \%$ of participants knew that people can donate every 4 months, this is higher than a study done in Benin, (21.5\%) but lower than a study conducted at Chennai (51.2\%) $[7,10,11]$. 
The majority of them were able to correctly mention that blood donation will transmit infections to the recipients and not the donors. This is consistent with finding from Chennai but lower when compared to a study conducted among health workers (72.2\%), and physicians in Benin (80.7\%) [10-12].

Only $34 \%$ of the study subjects knew that blood donation is good for donors health, which is much lower than a study conducted by Yene work Acham Jemberu and another study by Sanayaima DH etal $[8,13]$.

Age, sex, educational status and source of information were found to be independent predictors of knowledge of blood donation. Male study participants were more knowledgeable towards blood donation which is in line with findings from Karachi and North India $[14,15]$.

In Indian context, males are more accessible to information and spent most of their time out of their home than females. Having at least high school education was significantly and positively associated with the knowledge of blood donation, which is supported by a study conducted in Sikkim, India [16].

This could be because more educated people might be in a better position to access the media and availability of awareness creation at high school level in educational institutions.

A Study conducted in India and Addis Ababa carried out among health science students showed that knowledge of blood donation was higher as a result of their profession $[9,15]$. In the present study also, professionals had a better knowledge.

The composite measure of attitude indicates that only $44 \%$ of the respondents had favourable and positive attitudes towards blood donation. This is better than a study conducted in Karachi (42\%), however it is lower than similar studies conducted in India $(87.3 \%)$, Mekelle (61\%) and Addis Ababa $(68 \%)[7,9,14,15]$. Only less than one half had agreed that their members encourage them for donating blood in the future which is lower than other studies conducted in India and Addis Ababa $[9,13]$.

The most common reason quoted by our study subjects for not donating blood is fear of health problems followed by lack of opportunity and the same fact has been highlighted by several studies as the most common reason for not donating blood $[12,14,17]$.
The present study found that educational status, average monthly income, the source of information, and knowledge were significantly associated with a favourable attitude towards blood donation.

Participants who had higher monthly income were more likely to have a favourable attitude than lower income groups. This might be because those who have higher income may access better information sources.

In the present study $37.6 \%$ of respondents had reported at least one history of blood donation which is almost in par with similar studies conducted in Benin, Northern Nigeria, South India, and in Addis Ababa $[9,12,18,19]$. However, it is higher than other studies carried out in India $(13.9 \%)$ and Mekelle $(12 \%)[7,13]$.

The difference in the practice of blood donation could be due to variation in the setup of study settings since some of the studies were conducted among health professionals and some others were at school level.

In our study only $11.3 \%$ were voluntary donors and it was almost similar to the study done by $S$ Manikandanetal at Chennai and another study done by Jamunarani Srirangaramasamy in South India $[20,21]$.

The present study also indicates that $50 \%$ of the study subjects had encouraged others to donate blood and the results are almost similar to the study done at Gujarat [22]. So when it comes to practice only $33 \%$ of our study subjects had a good practice towards blood donation.

Global researchers also concluded that people are not donating blood because nobody approached them for donation, lack of information, unfit to donate, a need to donate for a friend or relative in future, fear of needle and knowing their viral status, the donated blood may be sold, non-remuneration, ignorance and their religion $[8-10,12,13]$.

Age, educational status, knowledge and attitude were significantly associated with the practice of blood donation. Older age groups were positively associated with the practice of blood donation. This is similar with findings from the studies conducted in Karachi and Iran [14,23].

This might be attributed to increased personal experience from donating blood. Having certificate and above educational level was associated with increased practice of blood donation which is 
Comparable with the study carried out in Addis Ababa [9].

The fact that this study was conducted at the community level could be mentioned as the strength of the study. The nature of cross-sectional study which is not possible to establish cause-effect relationship between the explanatory variables and outcome variables and the possibility of social desirability bias were among the limitations of this study.

\section{Conclusion}

The present study shows an average prevalence of knowledge and attitude among the study subjects whereas when it comes to practice it was found to be less. Middle aged people, male sex, higher educational standards, professionals and high socioeconomic groups had a better knowledge, attitude andpractice towards blood donation.

The finding of this study also justified any possible interventions on the independent predictors. There should be a regularly scheduled awareness creation and voluntary blood donation campaigns organized at the community level to utilize potential donors who lack the time and opportunity to donate blood.

\section{Acknowledgement}

We would like to express our heartfelt gratitude to all the study participants in the study, without them this research would not have been possible. We would like to extend our sincere appreciation to the medical officer Dr. Jebakkani, staffs of urban health centre, Pudupet who has provided us the relevant data and information related to our research work and finally our gratitude also goes to Dr. Rajesh who supervised the design and made critical comments at each step of research.

\section{Author's contribution}

Pugazhendiinban collected the data and entered in to the Microsoft office excel worksheet and Anand $\mathrm{N}$ performed analysis and interpretation of data and drafted the manuscript.Both the authors read and approved the final manuscript.

\section{The content the study adds to existing Knowledge}

The study provides information about the current practices of blood donation in the selected
Community is less and hence awareness is required to provide initiatives to voluntary blood donation and it is essential to improve the knowledge and attitudeabout blood donation among this community members by improving the educational level as there was a significant association between knowledge, attitude and practice on blood donation and educational level. Thus, this study will help to create a blood donor registry in the future to meet the needs of the recipients.

\section{Reference}

01. World Health Organization (WHO). BloodTransfusion Safety. Available from: [Article] [Crossref]

02. Unnikrishnan B, Rao $P$, Kumar N, Ganti $S$, Prasad R, Amarnath A, et al. Profile of blood donors and reasons for deferral in coastal South India. Australas Med J. 2011;4;379-85. [Crossref]

03. Campaign essentials world blood donor day 2016. 2016 [cited 2017 Jan 22];[14 screens]. Available from: [Article] [Crossref]

04. Glynn SA, Kleinman SH, Schreiber GB, Zuck T, Combs SM, Bethel J, Garratty G, Williams AE. Retrovirus Epidemiology Donor Study, Motivations to donate blood- demographic comparisons. Transfusion. 2002 Feb;42(2)21625.

[Crossref]

05. Singh B, Pandey RM, D'Souza N, Anushyanthan A, Krishna V, Gupta V, et al. Knowledge, Attitude and Socio-Demographic Factors Differentiating Blood Donors From Non-Donors in an Urban Slum of Delhi. Indian J Community Med. 2002;27(3)118-23.

[Crossref]

06. Donors Guidelines. 2017[ cited 2017 Jan 22]. [2 screens].

Available from: [Article] [Crossref]

07. Gebremeskel M, Girmatsion F, Lakew A, Zewda $B$, Mussie $A$. Intention to donate blood among the eligible population in Mekelle City, Northern Ethiopia- Using the theory of planned behavior. Am J Health Res. 2014;2(4)158-163.

[Crossref] 
08. Yenework Acham Jemberu, Ahmed Esmael, and Kedir Y Ahmed. Knowledge, attitude and practice towards blood donation and associated factors among adults in Debre Markos town, Northwest Ethiopia. BMC Hematol. $2016 ; 16(1) 23$.

doi: $10.1186 / \mathrm{s} 12878-016-0062-8 \quad$ [Crossref]

09. Chalachew M, Meaza T, Andualem D, Megdelawit $\mathrm{T}$, Tesfalem TT, Hawult T. The level and associated factors of knowledge, attitude and practice of blood donation among health science students of Addis Ababa University. Int J Med Health Sci Res. 2014;1(10)105-118.

[Crossref]

10. Benedict N, Usimenahon A, Alexander IN. Knowledge, Attitude and Practice of Voluntary Blood Donation among Healthcare Workers at the University of Benin Teaching Hospital, Benin City, Nigeria. J Blood Transfu. 2013;1-6. [Crossref]

11. Uma S, Arun R, Arumugam P. The Knowledge, Attitude and Practice towards Blood Donation among Voluntary Blood Donors in Chennai, India. J Clin Diagn Res. 2013;7(6)1043-1046. [Crossref]

12. Benedict N, Usimenahon A, Alexander NI, Isi A. Knowledge, attitude and practice of voluntary blood donation among physicians in a tertiary health facility of a developing country, Benin City, Nigeria. Int J Blood Transfus Immunohematol. 2012;2;4-10.

[Crossref]

13. Sanayaima DH, Jalina L, Shantibala K, Vijaya EL. Knowledge, Attitude and Practice (KAP) of Blood Safety and Donation. Ind Med Gaz. 2012;145(1)1-5.

[Crossref]

14. Ahmed Z, Zafar M, Khan AA, Anjum MU, Siddique MA. Knowledge, attitude and practices about blood donation among undergraduate medical students in Karachi. J Infect Dis Ther. 2014;2(2)1-4.

[Crossref]

15. Anju D, Atul S, Rahul C, Rajendra C. Knowledge, attitude and beliefs of people in North India regarding blood donation, Lucknow, India. Simtiservizisrl. 2014;12(1)21-27.

[Crossref]
16. Shenga N, Thankappan K, Kartha C, Pal R. Analyzing socio demographic factors amongst blood donors. J Emerg Trauma Shock. 2010;3(1)21-25.

[Crossref]

17. Dubey A, Sonker A, Chaurasia $R$, et al. Knowledge, attitude and beliefs of people in North India regarding blood donation. Blood Transfusion. 2014;12(Suppl1)21-7.

[Crossref]

18. Salaudeen AG, Musa OI, Awoyemi AO, Bolarinwa AO, Adegboye AO, Samuel SO. Community survey on blood donation practices in a northern state of Nigeria. J Prev Med Hyg. 2011;52;21-5. [Crossref]

19. Sabu KM, Remya A, Binu VS, Vivek R. Knowledge, Attitude and Practice on Blood Donation among Health Science Students in a University campus, South India. Online J Health Allied Scs. 2011;10(2)1-3.

[Crossref]

20. S Manikandan, R Srikumar, P N Ruvanthika. A Study on Knowledge, Attitude and Practice on Blood Donation among Health Professional Students in Chennai, Tamil Nadu, South India. International Journal of Scientific and Research Publications. 2013; Vol-3(3)1-4.

[Crossref]

21. Jamunarani Sriranga ramasamy, C P Luck, Madasamy Balamurugan, Karthick Subash Selvaraju, Ramya Mayakrishnan. A study on the knowledge, attitude, and practices regarding voluntary non-remunerated donation of blood among secondary school teachers in Tamilnadu. J Evolution Med Dent Sci. 2017; Vol-6(10)78590.

[Crossref]

22. Mullah F. Study of knowledge, perceptions and practices related to blood donation among the healthcare support staff of a tertiary care hospital in Gujarat, India. Online journal of Health and Allied Sciences. 2013 Mar;12(1)1-4. [Crossref]

23. Mousavi F, Tavabi AA, Golestan B, AmmarSaeedi E, Kashani H, Tabatabaei R, Iran-Pour E. Knowledge, attitude and practice towards blood donation in Iranian population. Transfus Med. 2011 Oct;21(5)308-17.

doi: $10.1111 / \mathrm{j} \cdot 1365-3148.2011 .01080 . x . \quad$ [Crossref] 